\title{
Impact of foliar spray of nutrients and seed treatment on protein uptake and protein yield of lathyrus (Lathyrus sativus L.) under relay cropping system
}

\author{
Mo. Navaz*, Anjum Ahmad, Sunil Kumar, G.K.Shrivastava, Veerendra Banjare and Anil Verma \\ Department of Agronomy, Indira Gandhi Krishi Vishwa Vidyalaya, Raipur (C.G.) India
}

(Email: naviwalananu1992@gmail.com)

\begin{abstract}
An experiment was carried out during the Rabi season of 2016, to study the impact of foliar spray of nutrients and seed treatment on protein uptake and protein yield of lathyrus (Lathyrus sativus L.) Under relay cropping system at the Agronomy Research Farm of IGKV, Raipur.The experiment was laid out in Factorial Randomized Block Design with twelve treatments replicated thrice. highest cost of cultivation, gross return, net return and $\mathrm{B}: \mathrm{C}$ ratio was found in treatment $\mathrm{F}_{5}: 0.5 \% \mathrm{NPK}(19: 19: 19)$ spray at branching and 15 days after $\mathrm{1}^{\mathrm{st}}$ spray $\left(11570.50,29492.64,18618.14,1.712 \mathrm{Rs}^{\mathrm{n}} \mathrm{h}^{-1}\right.$, respectively), where as in case of seed treatment $\mathrm{S}_{2}$ : seed treatment with Sodium molybdate @ $0.5 \mathrm{~g} \mathrm{~kg}^{-1}$ seed gave the maximum cost of cultivation, gross return, net return and B:C ratio $\left(11308.17,26475.39,15583.39,1.431\right.$ Rs.ha $^{-1}$, respectively).
\end{abstract}

Key Words : Lathyrus, Utera, Foliar spray, Seed treatment, Energetics

View Point Article : Navaz, Mo., Ahmad, Anjum, Kumar, Sunil, Shrivastava, G. K., Banjare, Veerendra and Verma, Anil (2021). Impact of foliar spray of nutrients and seed treatment on protein uptake and protein yield of lathyrus (Lathyrus sativus L.) under relay cropping system. Internat. J. agric. Sci., 17 (2) : 413-415, DOI:10.15740/HAS/IJAS/17.2/413-415. Copyright@2021: Hind Agri-Horticultural Society.

Article History : Received : 27.02.2021; Revised : 01.03.2021; Accepted : 16.03.2021

* Author for correspondence : 